\title{
TIFO 2019 - Translation and Interpreting Forum
}

\author{
(Csehország, Palacký Egyetem, Olomouc, 2019. november 15-16.)
}

\author{
Ugrin Zsuzsanna \\ E-mail:ugrinzsuzsa@gmail.com
}

Olomouc - vagy német nevén talán ismerösebben Olmütz - Morvaország egykori fővárosaként, érseki székhelyként évszázadokon át jelentős szerepet töltött be Közép-Európa szellemi életében; egyetemét 1573-ban - az ELTÉ-hez hasonlóan - a jezsuita rend alapította. Az intézmény, amely időközben a 19. századi morva történész-filozófus, František Palacký nevét vette fel, mára nyolc (többek között teológiai, jogi, orvos-, természet- és bölcsészettudományi) karán több mint 300 képzést kínál és mintegy 23 ezer hallgatóval rendelkezik, ezért „a cseh Oxfordnak” is nevezik.

A címben szereplö konferenciát a belváros egyik - tavaly gyönyörüen felújított - barokk épületében müködő bölcsészettudományi kar anglisztika-amerikanisztika tanszéke rendezte meg immár ötödik alkalommal. A 2011-ben útjára indított sorozat célja az, hogy az egyetemi kereteken túlnyúló, nyílt platformot biztosítson a nyelvek közötti kommunikáció minden szereplője számára. Ehhez a korábbi, 2011-ben, 2012-ben, 2014-ben és 2017-ben megrendezett konferenciák előadói és programja maximálisan igazodik, ugyanis plenáris előadókként a fordítástudomány olyan óriásai jelentek itt meg, mint Gerhard Budin (2011), Christina Schäffner (2012), Mona Baker és Juliane House (2014), valamint Franz Pöchhacker és Aline Remael (2017), a számos párhuzamos szekció pedig valóban kezdettől lefedi a fordítás, a tolmácsolás, illetve ezek technológiája és oktatása szinte minden területét; a 2014-es eseményen például a fordítástechnológia egyik legismertebb szakértője, Jost Zetzsche tartott CAT-workshopot. A tudomány mellett a piac képviselői - közöttük a Moravia, a Kilgray és az E-spell -, illetve az Európai Unió szakemberei is rendszeresen megjelennek a TIFO-n. A tematika minden évben átfogó: míg 2011-ben a módszertané volt a föszerep, addig a többi évben a hagyományok és a trendek, a minőség, illetve a nyelven túli dimenziók adtak keretet az előadásoknak. A résztvevők száma és nemzetközi változatossága minden alkalom-

Hivatkozás: Ugrin Zs. 2020. TIFO 2019 - Translation and Interpreting Forum (Csehország, Palacký Egyetem, Olomouc, 2019. november 15-16.) Fordítástudomány 22. évf. 1. szám. 105-108. DOI: https://doi.org/10.35924/fordtud.22.1.7 
mal egyre nőtt: egy szervező elmondása szerint 2017-ben közel 300 fö látogatott el az eseményre.

A 2019-es kiadás címe - ,Teaching Translation vs. Training Translators”, azaz „A fordítás oktatása és/vagy a fordítók képzése” - ezúttal kifejezetten a módszertanra helyezte a hangsúlyt, felvetve a klasszikus elmélet-gyakorlat dichotómiát. Az esemény az előző évekhez képest létszámban kissé szerényebb volt (a plenáris elöadásokon mintegy 100-150 fö vett részt), az előadók és a hallgatóság jellemzően Csehországból és a környező országokból (Szlovákia, Lengyelország) érkezett, de egy-két fővel Belgium, Bulgária, az Egyesült Királyság, Franciaország, Görögország, Olaszország, Oroszország és Spanyolország is képviseltette magát. Magyarországról e beszámoló szerzőjén kívül Szabó Csilla vett részt, szintén a BME-ről.

Plenáris előadókként ezúttal is egy-egy komoly szaktekintélyt hívtak meg - a címnek megfelelően - a fordítás elméleti, illetve gyakorlati oldaláról: előbbiröl a jelenleg a Tartui Egyetemen és a Leuveni Katolikus Egyetemen (KU Leuven) párhuzamosan oktató Jean-Luc van Dorslaert, utóbbiról a számos szakmai szervezetben aktív, Párizsban élő amerikai szabadúszó szakfordítót, Chris Durbant.

Az első napon, a hivatalos megnyitó után van Dorslaer előadása széleskörü áttekintést nyújtott a fordítás- és tolmácsolástudomány aktuális állapotáról. „Miért túl leegyszerüsítő az « elmélet és gyakorlat » ellentét?" (saját fordítás) - a konferencia tematikájával polemizáló cím mögött van Dorslaer számos szempontból körüljárta a nyelvi közvetítés mint tudomány és szakma aktuális dilemmáit és paradigmaváltásait. Ma, amikor a szakma határai egyre tágulnak, és az egykori statikus, elöíró paradigma a folyamatos változást leíró, dinamikus percepciónak ad teret, a kutatás négy területen segítheti a gyakorlatot: nyelvészeti (forrás- és célszöveg kapcsolata, ekvivalencia), kulturális (interkulturalitás, hatalom és ideológia), kognitív (gépelés- és szemmozgáskövetés), illetve szociológiai (a fordítás mint termék, mint státusz, mint folyamat stb.) megközelítésből. A valódi dilemma immár nem az elmélet és a gyakorlat között húzódik, hanem a fordításról mára kialakult két felfogás között. Ezek egyike szerint a fordítás nem más, mint a célnyelvi szövegeket a technológia segítségével könnyen és gyorsan, alacsony kockázattal elöállító, akár gépi fordítással is kiváltható „termelés”, míg a másik, tágabb értelmezés a szövegeken jóval túlmutató, kultúrák és médiumok között sokrétúen közvetítő transzkreációt helyezi előtérbe. Ezek között kell a mai nyelvi közvetítőknek és kutatóknak eligazodni, így van Dorslaer az elmélyült remete, Szent Jeromos statikus alakja helyett az istenek és halandók között közvetítő, szemfüles, fürge, a határokat át- meg áthágó tolvaj-istent, Hermészt tenné meg a szakma védelmezőjének.

A nyitóelőadást követő panelbeszélgetésen van Dorslaer, Chris Durban, illetve a cseh fordító- és tolmácsszakmát gyakorlati és oktatói oldalról képviselő szakemberek a fenti dilemmákat járták körül. Egy olyan világban, amelyben a fordítók napi tíz órában gépi fordítást utószerkesztenek, a hallgatók pedig mobiltelefonon és tableten készítik el feladataikat, tudatosan őrizni kell a kontaktust a nyelv ,emberi” oldalával, szem előtt tartva a nyelvi közvetítői szerepek sokszínüségét, lehetöségeit és korlátait. 
A délutánt két, három-három teremben zajló szekció-blokk töltötte ki: ezek témája a fordítói piac, a projektalapú fordítóképzés és a szinkrontolmácsolás, valamint a fordítástechnológia, a fordítóképzésben alkalmazott értékelés és a müfordítás volt. Szabó Csilla a BME-n megvalósított, a piacorientált, inkluzív fordítóképzést támogató e-TransFair projektet az első szekcióban ismertette, míg ezzel párhuzamosan cseh, lengyel és spanyol kollégák mutatták be különféle kollaboratív, a hallgatók számára „éles” helyzeteket teremtő projektjeiket, legyen szó egy irodalmi mü (később kiadott!) csoportos fordításáról vagy egy projektfeladat-kezelö alkalmazás, a Trello fordításórai kipróbálásáról. A szerző a fordítástechnológiai szekcióban számolt be - szintén a BME eTransFair projektje kapcsán - arról, hogyan jelenik meg a fordítóképzések tanmenetében, s ez alapján hogyan fejleszthető a technológiai kompetencia. A szekció többi előadása a fordítás ma elengedhetetlen számítógépes eszközeiröl (Viktorija Petrova, Szófia), az információkereső kompetencia szakfordítás-beli fejlesztéséről (Joanna Sycz-Opon, Katowice), illetve a fordítási folyamatot és a mesterséges intelligenciát összekapcsoló, vektoralapú modellezési módszerről szólt (Ivona Misterová, Pilsen).

A nap lezárásaként a szervezők színvonalas kultúrprogramot és ízletes vacsorát biztosítottak az egyetem egy másik régi, szintén nemrégiben felújított épületében: a pazar barokk freskókkal és szobrokkal díszített kis Corpus Christi kápolnában az egyetem zenemüvészeti karának növendéke énekelt zongorakísérettel, majd az aulában - a menüjével a nem sokkal korábbi Szent Márton-napra emlékező - fogadás várta a konferencia résztvevőit.

A szombati napot Chris Durban előadása nyitotta „Translation, time, technology - who's counting?” („Fordítás, idő, technológia - ki számol?”) címmel. Minek alapján számítjuk a fordításunk értékét? Jó mutató-e a ráfordított idő, és emeli vagy csökkenti-e a munkadíjat az alkalmazott technológia? Durban számos, saját tapasztalatából vett - néha mulatságos, néha megdöbbentő - példával illusztrálta a téma körüli bizonytalanságot és tévhiteket, majd néhány igen tanulságos kiosztmánnyal illusztrálta a különbséget több müfajhoz tartozó szövegek ingyenes, illetve gépi fordítómotor, valamint „olcsó” és „,prof”” fordító által (franciáról angolra) készített fordítása között. A következtetés hatásos volt: az olcsó (kevés pénzért gyorsan és silányul dolgozó) fordító munkája nem múlja felül a neurális fordítómotorok által (gyakorlatilag ingyen) létrehozott produktumot, így ezekre a szakemberekre - illetve bizonyos szakterületeken az emberi fordítókra - a jövőben nem lesz szükség. Fordítóként tehát az egyetlen út a minőségi, így időigényes munka, amelynek jól megérdemelt árát tudatosítani kell a megbízóban is. A kiosztott táblázatok alapján pedig a silány és a minőségi munka közötti különbség a kultúratudatosságban és a megfelelően alkalmazott explicitációban rejlik - ott, ahol erre valóban szükség van.

A délelőttöt ezután két szekció-blokk töltötte ki (tolmácsképzés; jogi szakfordítás / törvényszéki tolmácsolás, valamint a tolmácsolás ügyfelei; fordítás az angol nyelvoktatásban). A jogi fordítást Tomás Duběda (Prága) az idegen nyelvre fordítás oktatásán keresztül mutatta be, ahol a hallgatók munkáját jogi szakemberek, illet- 
ve laikusok értékelték holisztikus és analitikus módon; a szakértők jóval több terminológiai, stilisztikai és jelentésbeli hibát azonosítottak, ezzel pontosabb viszszajelzést biztosítva a hallgatóknak. Ezután Esther Vázquez y del Árbol (Madrid) a külön a jogi szakfordítók számára kifejlesztett kompetenciasémát ismertette, ahol a tematikus, a terminológiai és a számítógépes aspektus mellett egyenrangú szerepet kap a dokumentációs és a szövegkompetencia is.

Az elöadás-blokkok közötti hosszabb kávészünetekben alkalom nyílt a kollégákkal való eszmecserére, s bár a jobban összeszokott cseh szakmai közösségen belül érezhetően élénkebb kommunikáció folyt, azért sikerült ismeretséget kötni néhány kollégával és rávilágítani a minden fordítás- és tolmácsolásoktató számára közös aktuális kihívásokra, illetve a Közép-Európára általánosan jellemző jelenségekre (például az idegen nyelvre való fordítás súlya vagy a megbízók, megbízások heterogenitása).

Összességében elmondható, hogy a TIFO-konferenciasorozatot érdemes tudatosítani a környező országokban zajló szakmai események között. Egyrészt azért, mert a - nyitott és segítőkész - szervezők rendkívüli igényességgel és széles látókörrel állítják össze az egyes kiadások programját, másrészt azért, mert az egyetemi és a piaci közeg optimális aránya jó alkalmat nyújt az - akár intézményközi, akár személyes - kapcsolatépítésre, harmadrészt pedig azért, mert a szervezők - az egyébként szerény részvételi díj mellé némi többletköltség fejében - az előadásokból írt tanulmányok angol nyelvü publikálására is lehetőséget biztosítanak. Mindemellett Olomouc festői kisvárosa középkori és későbbi emlékeivel, múzeumaival, természeti környezetével akár egy hosszabb itt-tartózkodást is megér.

A konferencia honlapja: https://tifo.upol.cz/ 